\title{
Characterization of FeCo based catalyst for ammonia decomposition. The effect of potassium oxide
}

\author{
Zofia Lendzion-Bieluń $^{1 *}$, Rafal Pelka ${ }^{1}$, Lukasz Czekajło ${ }^{1}$ \\ ${ }^{1}$ West Pomeranian University of Technology, Szczecin, Institute of Inorganic Chemical Technology \\ and Environmental Engineering, Poland, 70-322 Szczecin, Pułaskiego 10; E-mail: rpelka@zut.edu.pl, \\ lukaszczekajlo@wp.pl \\ * Zofia Lendzion-Bieluń; E-Mail: zosi@zut.edu.pl; \\ Tel.: +48-91-449-4730; Fax: +48-91-449-4686.
}

Received: 7 April 2014 / Accepted: 14 May 2014 / Published: 26 May 2014

\begin{abstract}
FeCo fused catalyst was obtained by fusing iron and cobalt oxides with an addition of calcium, aluminium, and potassium oxides $\left(\mathrm{CaO}, \mathrm{Al}_{2} \mathrm{O}_{3}, \mathrm{~K}_{2} \mathrm{O}\right)$. An additional amount of potassium oxide was inserted by wet impregnation. Chemical composition of the prepared catalysts was determined with an aid of the XRF method. On the basis of XRD analysis it was found that cobalt was built into the structure of magnetite and solid solution of $\mathrm{CoFe}_{2} \mathrm{O}_{4}$ was formed. An increase in potassium content develops surface area of the reduced form of the catalyst, number of adsorption sites for hydrogen, and the ammonia decomposition rate. The nitriding process of the catalyst slows down the ammonia decomposition.
\end{abstract}

Keywords: ammonia decomposition; hydrogen; catalyst FeCo

\section{Introduction}

Intensive investigations over hydrogen usage as a source for energy production are being conducted currently. Hydrogen application encompasses energy production in fuel cells, in stationary as well as portable devices. The fuel cells applications in transport means seem to be especially promising [1]. Hydrogen production in the ammonia decomposition reaction has some advantages in comparison with conventional methods as steam reforming, coal gasification, and biomass catalytic gasification. First of 
all hydrogen from the ammonia decomposition contains no $\mathrm{CO}_{\mathrm{x}}$, which have poisoning impact on catalysts for fuel cells [2]. Liquid ammonia may be easier stored than hydrogen [1]. Infrastructure for ammonia production is developed very well and technology of ammonia is well known.

Taking into consideration ammonia decomposition thermodynamics it is a convenient process. At $400{ }^{\circ} \mathrm{C}$, under $1 \mathrm{~atm}$. equilibrium degree reaches a value above 99\% [3]. The ammonia decomposition reaction is being studied intensively to find new systems of active catalysts.

Previous investigations showed that elements from group VIII ( $\mathrm{Ru}, \mathrm{Fe}, \mathrm{Co}, \mathrm{Ni}, \mathrm{Ir}, \mathrm{Rh})[3,4,5,6]$ and carbides/nitrides[7,8] of molybdenum, vanadium, and tungsten catalyses ammonia decomposition reaction into hydrogen and nitrogen. Supported ruthenium catalysts show the highest activity in the ammonia decomposition reaction [3]. The limiting stage of the ammonia decomposition is a desorption of nitrogen atoms[9].

Iron binds nitrogen atoms strongly, iron catalyst surface saturates itself what finally, especially at lower temperatures, leads to a kind of poisoning [10]. Ammonia decomposition rate depends on a degree of nitrogen saturation of the iron surface. Limited availability of noble metals and a relatively low activity of non-noble metals induce to further works on optimization of catalytic systems for ammonia decomposition working at lower temperatures. Both theoretical $[5,9,11]$ and experimental studies [12] show that bimetallic systems are promising catalysts for that reaction. The fundamental rule of that idea is to bind together to metals with opposite affinity towards nitrogen atoms e.g. CoMo or $\mathrm{FeCo}$.

The activity of catalysts in the ammonia decomposition reaction is connected with a sort and content of promoters. Special role is played by electron-donor promoters such as potassium [3], caesium[13] or barium[14]. In the studies [13] it was presented that an increase in caesium content in ruthenium/nanotubes catalyst had caused an increase in ammonia decomposition degree and an decrease in the activation energy.

In this paper the impact of potassium oxide content on structural and catalytic properties of $\mathrm{FeCo}$ catalyst is presented. Distribution of nanocrystallites size in the reduced form of the catalyst, made according to the previously elaborated method based on measurements of the rate of the nitriding reaction of the catalyst, is presented.

\section{Experimental}

FeCo fused catalyst was obtained by fusing magnetite with an addition of calcium, aluminium, and potassium oxides $\left(\mathrm{CaO}, \mathrm{Al}_{2} \mathrm{O}_{3}, \mathrm{~K}_{2} \mathrm{O}\right)$. During the melting process cobalt(II, III) oxide was added . The prepared alloy of the catalyst was crushed and formed grains of the diameter in the range from 1.0 to $1.2 \mathrm{~mm}$ were separated for tests. Chemical compositions of the catalyst was determined with the aid of the X-ray fluorescence method (XRF) using Panalytical spectrometer, non-standards Omnian method was applied. XRD method was applied to identify catalyst phase composition before and after tests (Philips X'Pert Pro). Measurements of the specific surface area of the catalyst in the reduced form were performed using a single-point BET method with an AutoChem II 2920 Micromeritics apparatus. Before tests samples were being reduced with hydrogen at $600^{\circ} \mathrm{C}$ by 16 hours.

In order to increase a content of potassium in the catalyst, catalyst was impregnated with water solution of $\mathrm{KOH}$. Before the impregnation process, the catalyst was reduced. The reduction process 
was carried out at hydrogen atmosphere $(99,999 \%)$ from $20{ }^{\circ} \mathrm{C}$ to $600{ }^{\circ} \mathrm{C}$ with a heating rate of $15^{\circ} \mathrm{C} /$ min. under ambient pressure.

A series of kinetic measurements of the nitriding process was made for $100 \%$ ammonia at a reactor inlet and next nitrides reduction with pure hydrogen at $400{ }^{\circ} \mathrm{C}$. Results of these measurements were used to determine a size distribution of the crystallites with a chemical method described in a paper [15]. This method allows to determine a size distribution of crystallites of the reduced form of the catalysts.

Activity tests of the catalyst in the ammonia decomposition reaction were carried out in a differential reactor connected with thermogravimeter. Some $0.5 \mathrm{~g}$ of the oxidized catalyst of granulation of $1.0-1.2 \mathrm{~mm}$ was placed in a platinum basket as a monolayer bed. Before the ammonia decomposition and the nitriding tests, catalyst was reduced with pure hydrogen at $600{ }^{\circ} \mathrm{C}$. Measurements of catalysts activity were performed in the temperature range from 400 to $600{ }^{\circ} \mathrm{C}$ under ambient pressure. The ammonia decomposition reaction was tested in the range of ammonia concentration at the reactor inlet from 0 to $100 \%$. Total gas flow was constant $-200 \mathrm{sccm}$.

Changes of the gas phase, ratio $\mathrm{NH}_{3} / \mathrm{H}_{2}$, at the reactor inlet were made after reaching a stationary state and when all tests at these conditions were made. Gas phase content changes at the reactor inlet were made to change the value of the nitriding potential $\mathrm{P}=\mathrm{p}_{\mathrm{NH} 3} / \mathrm{p}_{\mathrm{H} 2}{ }^{1.5}$ at the reactor.

The concentration of hydrogen at the outlet of the reactor was measured on the basis of the thermal conductivity of gas and the concentration of hydrogen assuming stoichiometric decomposition of ammonia at the stationary state [6]. Conversion degree of ammonia $\alpha_{\mathrm{NH} 3}$ was calculated from an equation 1.

$$
\text { Eq. [1] } \quad \alpha_{\mathrm{NH} 3}=\frac{X_{H_{2}} F^{o}-F_{H_{2}}^{o}}{F_{N H 3}^{o}\left(1.5-X_{H_{2}}\right)}
$$

Where: $\mathrm{F}^{\mathrm{o}}$ - total gaseous reactants flow at the reactor inlet, $\mathrm{mol} \cdot \mathrm{s}^{-1}, \mathrm{~F}^{\mathrm{o}} \mathrm{H} 2$ and $\mathrm{F}_{\mathrm{NH} 3}^{\mathrm{o}}$ - hydrogen and ammonia flows at the reactor inlet, $\mathrm{mol} \cdot \mathrm{s}^{-1}, \mathrm{X}_{\mathrm{H} 2}-$ molar concentration of hydrogen in the reactor, mol $\cdot \mathrm{mol}^{-1}$.

On the basis of degree of ammonia decomposition under given conditions of temperature and ammonia flow rate at the reactor inlet the rate of the ammonia decomposition reaction, related to mass of catalyst, was calculated from an equation 2.

$$
\text { Eq. [2] } \quad \mathrm{r}_{\mathrm{decomp}}=\alpha_{\mathrm{NH} 3} \cdot F_{\mathrm{NH} 3}^{o} / \mathrm{m}_{\mathrm{cat}}
$$

Where: $\alpha_{\mathrm{NH} 3}$-degree of ammonia decomposition, $F_{N H 3}^{o}$ ammonia flow in the reactor inlet, $\mathrm{mol} \cdot \mathrm{s}^{-1}$, $\mathrm{m}_{\text {cat }}$ - mass of catalyst, $\mathrm{g}$.

A gas phase analysis and changes taking part in the solid phase during the ammonia decomposition process were being observed simultaneously.

\section{Results and Discussion}

Chemical composition of the catalyst obtained in the melting process was determined with XRF method and was as follows: $1.05 \mathrm{wt} \% \mathrm{Al}_{2} \mathrm{O}_{3}, 1.23 \mathrm{wt} \% \mathrm{CaO}, 0.21 \mathrm{wt} \% \mathrm{~K}_{2} \mathrm{O}, 4.8 \mathrm{wt} \% \mathrm{Co}_{3} \mathrm{O}_{4}$. The rest was composed of iron oxide $\mathrm{Fe}_{3} \mathrm{O}_{4}$. As a result of potassium hydroxide impregnation two additional catalysts were prepared with potassium oxide content of $0.47 \mathrm{wt} . \%$ i $0.87 \mathrm{wt} . \%$ respectively. In that 
way three catalysts varying one another of potassium oxide content, what was included into the catalyst names $\mathrm{FeCo}(0.21), \mathrm{FeCo}(0.47), \mathrm{FeCo}(0.87)$, were prepared.

On the basis of XRD analysis, Fig. 1, it was found that cobalt atoms were built into magnetite structure forming a solid solution. $\mathrm{X}$ - ray peaks were attributed to $\mathrm{CoFe}_{2} \mathrm{O}_{4}$ phase according to the JCPDS (01-077-0426) card .

Figure1. X-ray pattern of the oxidized form of the $\mathrm{FeCo}(0.21)$ catalyst.

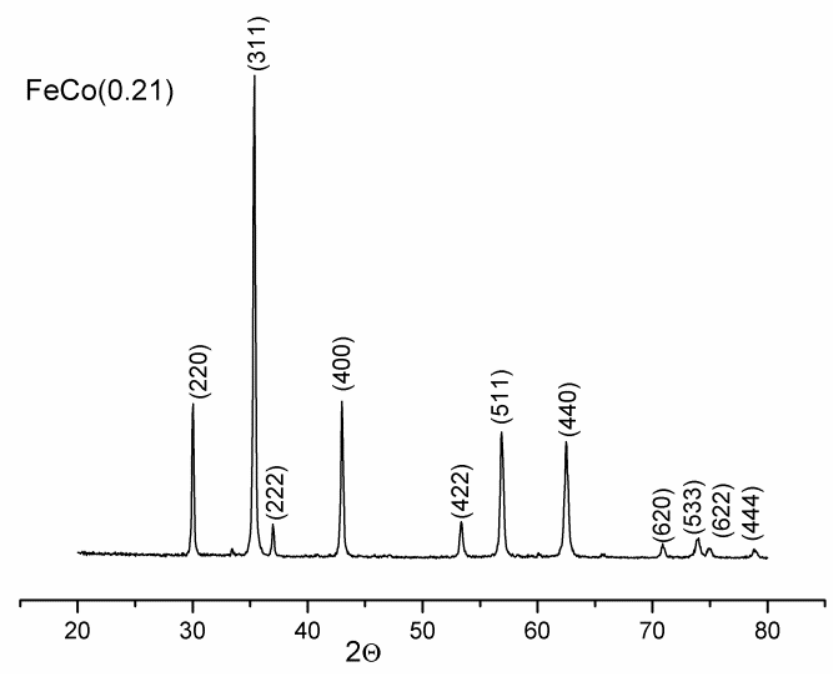

An insert of additional amount of potassium oxide into the system did not have an influence on a phase content of the catalysts, X-ray patterns were not presented.

Specific surface areas of the reduced forms of the catalysts and volumes of desorbed hydrogen after TPD $-\mathrm{H}_{2}$ process were showed in Table 1 . The specific surface of the reduced catalysts increase while potassium oxide content rises. The increase in the specific surface area influences on a sorption of hydrogen.

Table 1. Specific surface area of the catalysts in the reduced form and volume of absorbed hydrogen in the TPD- $\mathrm{H}_{2}$ process.

\begin{tabular}{|c|c|c|}
\hline Catalyst & $\begin{array}{c}\mathrm{S}_{\mathrm{BET}} \\
{\left[\mathrm{m}^{2} / \mathrm{g}_{\text {cat }}\right]}\end{array}$ & $\begin{array}{c}\mathrm{V}_{\mathrm{H} 2} \\
{\left[\mathrm{~cm}^{3} / \mathrm{g}_{\text {cat }}\right]}\end{array}$ \\
\hline \hline $\mathrm{FeCo}(0.21)$ & 10.50 & 0.3085 \\
\hline $\mathrm{FeCo}(0.47)$ & 11.28 & 0.3111 \\
\hline $\mathrm{FeCo}(0.87)$ & 12.49 & 0.3154 \\
\hline
\end{tabular}

Changes of katharometer signal, connected with changes of hydrogen content and temperature for catalysts with various content of potassium oxide are presented in Fig. 2. 
Figure 2. TPD- $\mathrm{H}_{2}$ of the catalysts modified with potassium.

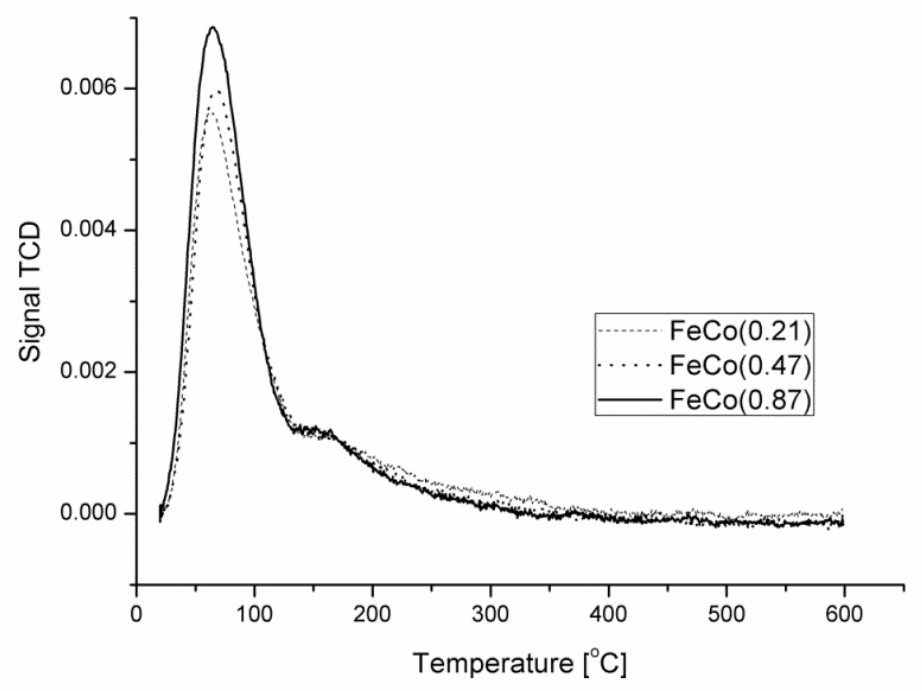

Two maxima were observed on the curve of TPD- $\mathrm{H}_{2}$, the first one at about $66{ }^{\circ} \mathrm{C}$ and the second one at about $165^{\circ} \mathrm{C}$. With the increase in the $\mathrm{K}_{2} \mathrm{O}$ content in the catalyst number of active adsorption sites for hydrogen with weaker bond energy on the catalyst surface increases too.

Results of measurements of nitriding degree of $\mathrm{FeCo}(0.21)$ catalyst in the nitriding process (ammonia of $100 \%$ at the reactor inlet, temperature of $400{ }^{\circ} \mathrm{C}$ ) and nitrides reduction were showed in Fig. 3. Nitriding degree, $\mathrm{m}_{\mathrm{N}}$, was defined as a ratio of nitrogen mass at the given moment of the process to mass of metallic phase of $\alpha-\mathrm{FeCo}, \mathrm{m}_{\mathrm{FeC}}$. In the plot changes of hydrogen content in the gas phase during the reaction were also presented. Contents of the others components of gas phase were determined on the basis of the reactor mass balance.

Figure 3. Thermogravimetric curve and changes of hydrogen content determined for nitriding process of the alloy $\mathrm{FeCo}(0.21)$ catalyst (ammonia content at the reactor inlet $-100 \%$, temperature $\left.400{ }^{\circ} \mathrm{C}\right)$

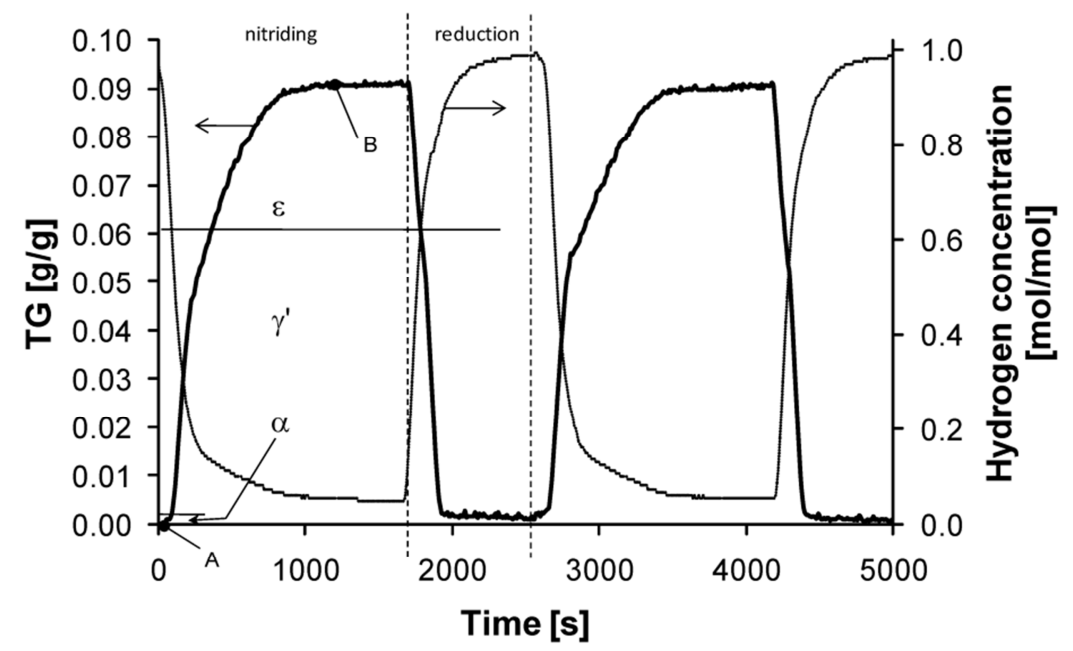


An observed mass change of the catalyst, $0.003 \mathrm{~g} / \mathrm{g}$, in the initial stage (about $100 \mathrm{~s}$ ), was connected with a nitrogen dissolution in the metallic phase of $\alpha-(\mathrm{FeCo})$. In the next stage an increase in mass runs until reaching an inflection point at $\mathrm{m}_{\mathrm{N}}=0.053 \mathrm{~g} / \mathrm{g}$ connected with formation of $\gamma^{\prime}-$ $(\mathrm{FeCo})_{4} \mathrm{~N}$ phase and its saturation with nitrogen. Above that level a new phase, $\varepsilon-(\mathrm{FeCo})_{3} \mathrm{~N}$, comes into being. Mass stabilization takes place at $\mathrm{m}_{\mathrm{N}}=0.09 \mathrm{~g} / \mathrm{g}$. Stationary state was settled, in which mass of the catalyst and gas phase composition are constant. Next, obtained nitrides were reduced with hydrogen.

Nitriding degree and shapes of TG curves obtained in several cycles ( on the plot only two cycles are presented, in fact many cycles were carried out) are the same, what indicates to catalyst structure stability during the run of experiment.

Analysing the nitriding process, it can be noticed that mass of the sample and gas phase composition were stabilized after about $1000 \mathrm{~s}$. During the reduction stabilization of the solid phase is very fast $-300 \mathrm{~s}$, while gas phase needs more time to be stabilized, what is sometimes connected with gas exchange in the reactor.

After differentiating $\mathrm{AB}$ curve interval form Fig. 3, the rate of nitriding process was determined (Fig. 4.).

Figure 4. Nitriding reaction rate (ammonia content at the reactor inlet $-100 \%$, temperature -400 $\left.{ }^{\circ} \mathrm{C}\right)$.

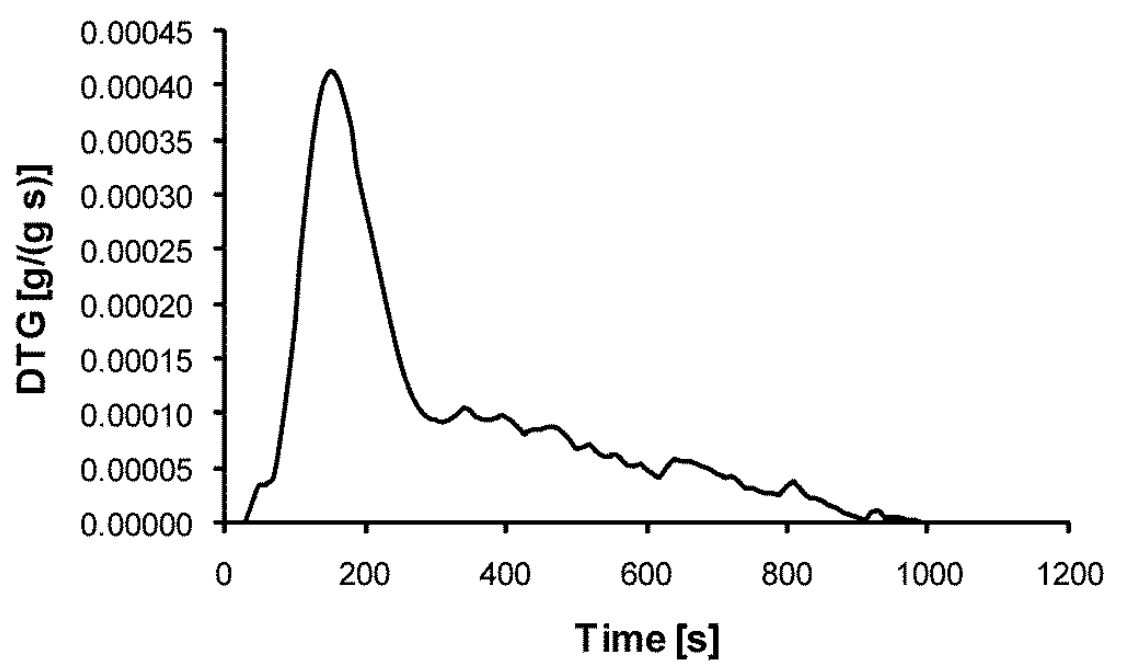

After transformation function from DTG $=f(t)$ into DTG $=f(\alpha)$ rates of forming $\gamma^{\prime}$ and $\varepsilon$ phases were separated (Fig. 5). Conversion degree $\alpha$ defined as ratio of mass of bound nitrogen at given while of the reaction and mass of nitrogen in just forming $\gamma^{\prime}$ nitride phase. 
Figure 5. Rate of nitriding reactions of $\alpha$-FeCo into $\gamma^{\prime}$ phase and $\gamma^{\prime}$ phase into $\varepsilon$ phase, (ammonia content at the reactor inlet $-100 \%$, temperature $-400{ }^{\circ} \mathrm{C}$ ).

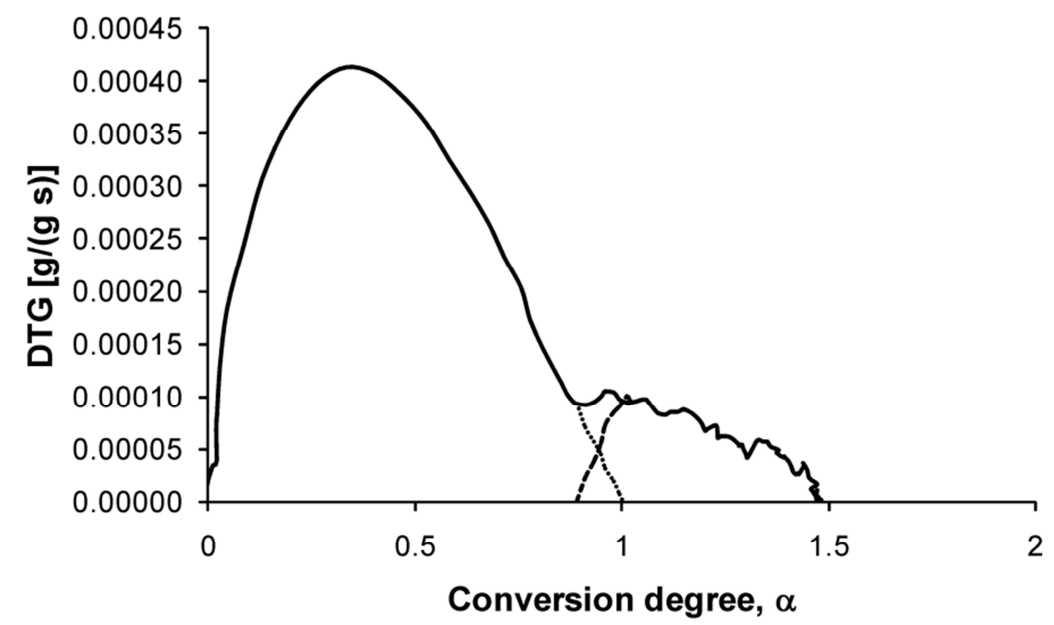

For further calculation data concerning the rate of $\gamma^{\prime}$ phase forming were applied. The rate of the nitriding reaction as a function of nanocrystallites size distribution may be described by the following equation :

$$
r_{\text {nit }}=k\left(P-P_{0}\right) f(\alpha)
$$

$\mathrm{k}$ - nitriding reaction rate constant; $\mathrm{P}_{0}-$ minimum nitriding potential required to start the nitriding reaction.

On the basis of the above equation and an assumption that specific surface area equals $10.5 \mathrm{~m}^{2} / \mathrm{g}$, distribution of nanocrystallites size was determined.

Figure 6. Distribution of nanocrystallites size the reduced FeCo catalyst.

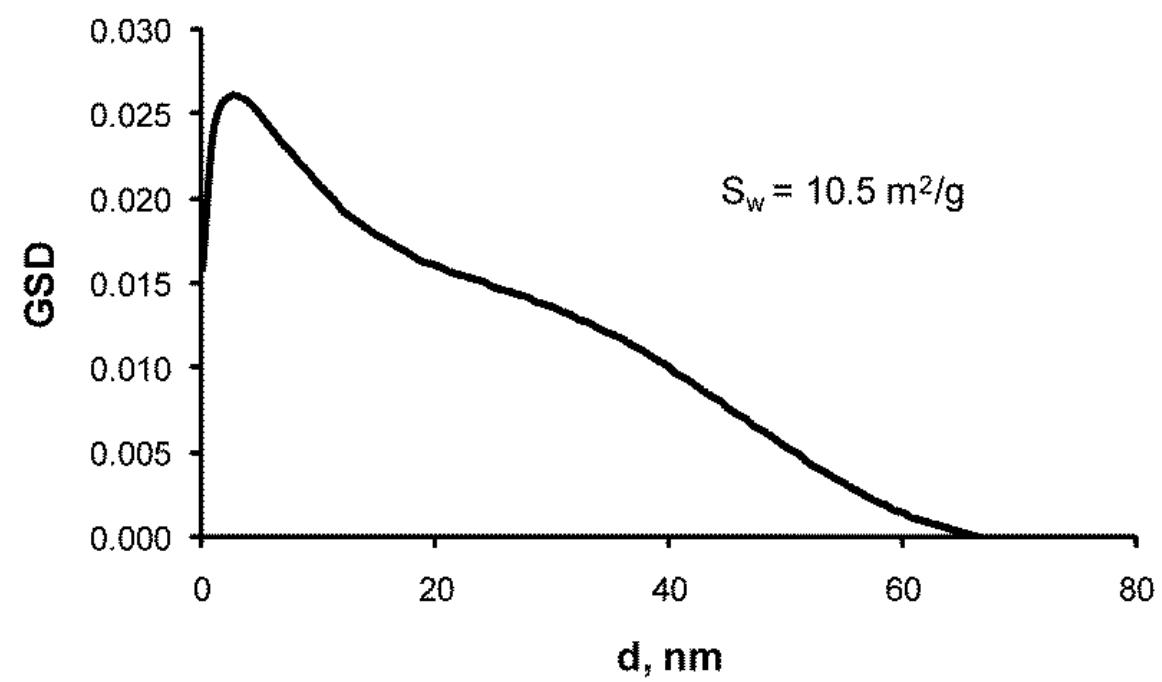


From the distribution crystallites size showed in Fig. 6 it was found that crystallites of various size are presented in the catalyst. Crystallites of about $5 \mathrm{~nm}$ size participate in the largest volume, next maximum is visible for $30 \mathrm{~nm}$.

The characterized material was used to make measurements of the rate of the ammonia catalytic decomposition at conditions of ammonia content at the reactor inlet in the range from 0 to $100 \%$. Results of thermogravimetric measurement and changes of hydrogen content in the gas phase at the reactor outlet as a function of time were plotted in Fig. 6.

Figure 6. Hydrogen concentration changes and the nitriding degree vs. time at temperature $400{ }^{\circ} \mathrm{C}$.

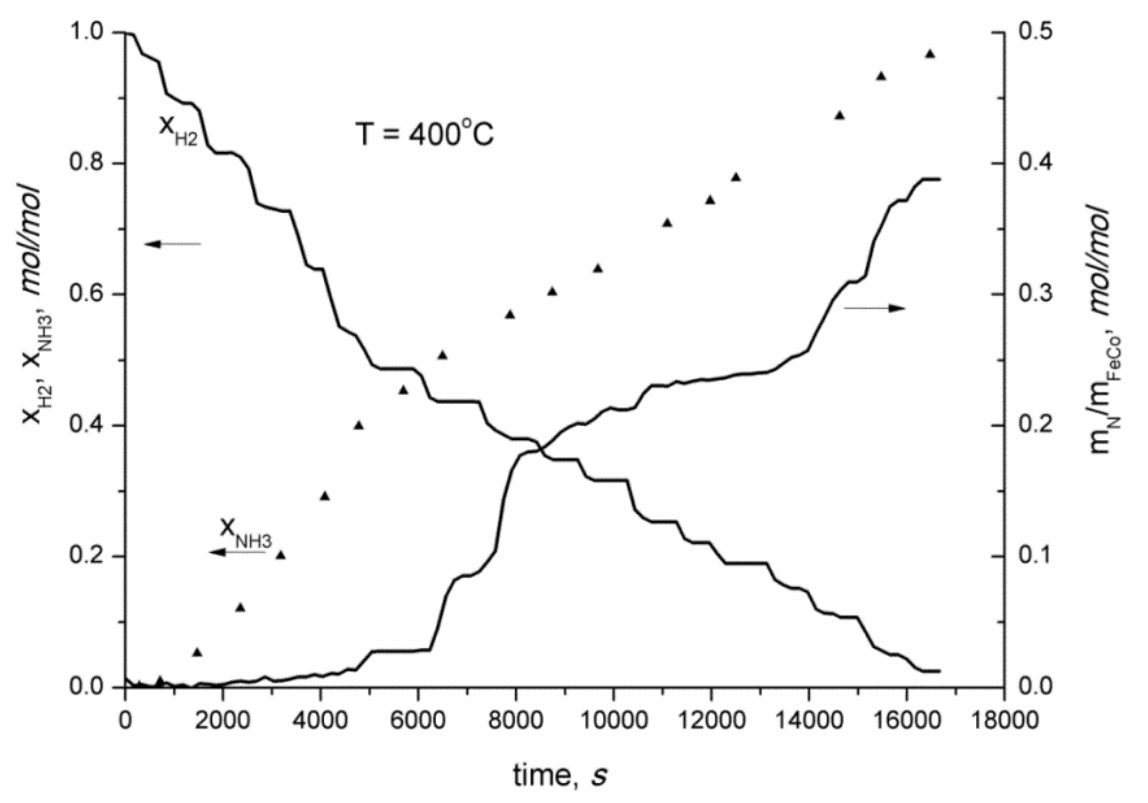

Stationary states, in which hydrogen content do not change and the ammonia decomposition rate is constant, settle in about $500 \mathrm{~s}$ after a step change in gas mixture feeding the reactor. Catalyst mass change connected with the nitriding process was also observed. It was expressed as a ratio of number of moles of nitrogen and number of moles of catalyst. The maximum increase in catalyst mass was registered for $\varepsilon$ phase.

Changes of the ammonia decomposition reaction rate as a function of logarithm of nitriding potential $\left(\ln \mathrm{P}=\mathrm{p}_{\mathrm{NH} 3} / \mathrm{p}_{\mathrm{H} 2}{ }^{1.5}\right)$ at temperatures of 600,550 , and $475^{\circ} \mathrm{C}$ and mass changes of the catalysts during the ammonia decomposition process at $475^{\circ} \mathrm{C}$ are shown in Fig. 7. 
Figure 7. Dependence of the ammonia decomposition rate as a function of nitriding potential $\left(\ln \mathrm{P}=\mathrm{p}_{\mathrm{NH} 3} / \mathrm{p}_{\mathrm{H} 2}{ }^{1.5}\right)$ for the catalyst with a low content of potassium oxide: a) at $\left.600{ }^{\circ} \mathrm{C}, \mathrm{b}\right)$ at $\left.550{ }^{\circ} \mathrm{C}, \mathrm{c}\right)$ at $475{ }^{\circ} \mathrm{C}$, d) mass changes of the catalysts during the ammonia decomposition process at $475{ }^{\circ} \mathrm{C}$ as a function of the logarithm of the nitriding potential.
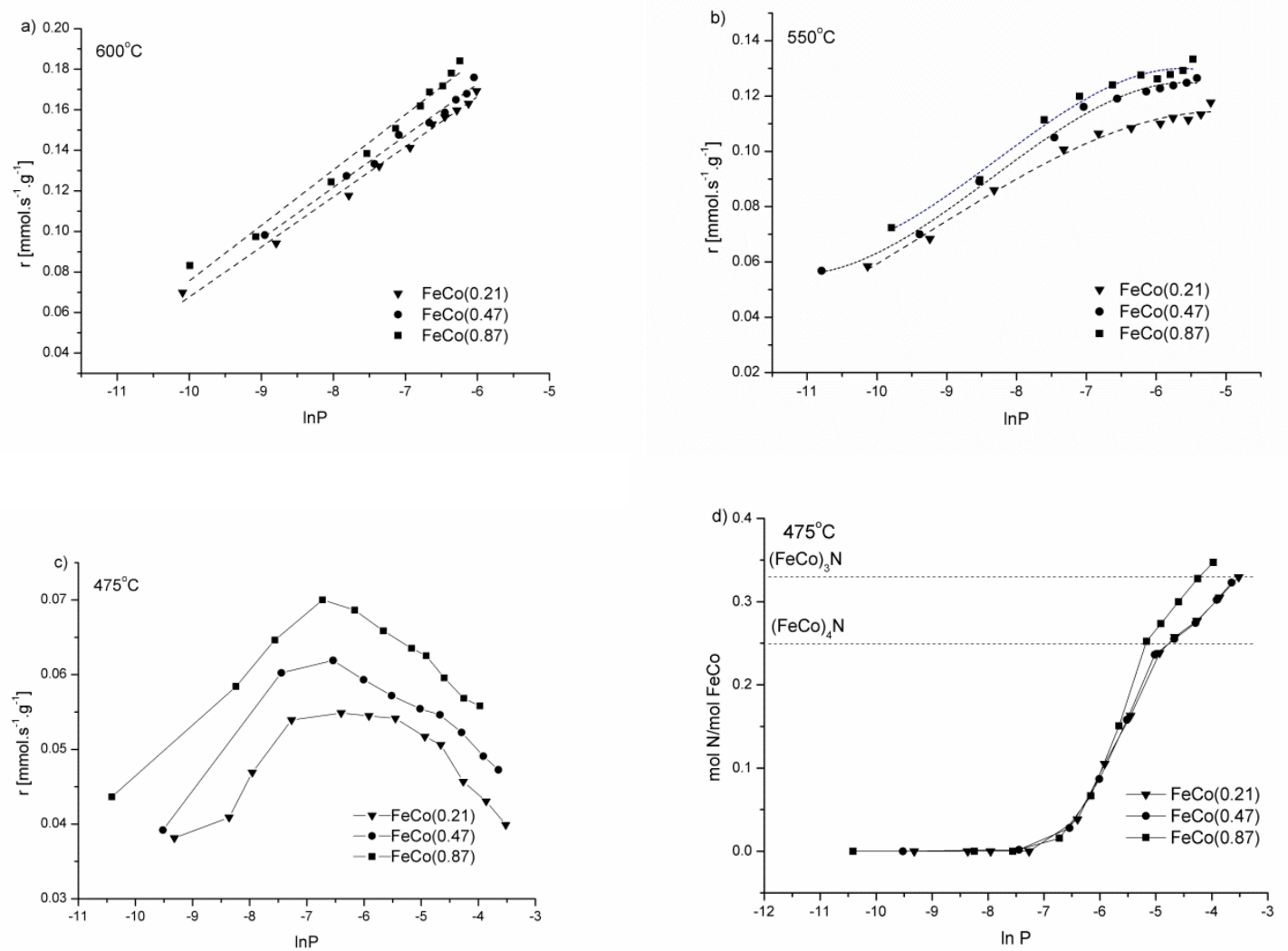

Ammonia decomposition rate was calculated from gas phase content in stationary states. At $600^{\circ} \mathrm{C}$ the rate ammonia decomposition increases while nitriding potential increases. At these conditions mass changes of the catalyst were not observed. At $550{ }^{\circ} \mathrm{C}$ it was observed that from a value of nitriding potential of about $\ln \mathrm{P}=-7$ tha ammonia decomposition rate settles at a constant level. Mass change, $0.1 \mathrm{~mol} \mathrm{~N} / \mathrm{mol} \mathrm{FeCo}$, was also observed. At the lower temperature of $475{ }^{\circ} \mathrm{C}$, above $\ln \mathrm{P}=-7$ a decrease in the reaction rate was registered. Simultaneously a decrease in the reaction rate and an increase in catalyst mass were measured. The dependence of catalyst mass changes as a function of logarithm of nitriding potential was presented in Fig. 7d. While ammonia content in the reactor increases catalyst mass increases too. Stoichiometric compositions corresponding to $\gamma-(\mathrm{FeCo})_{4} \mathrm{~N}$ i $\varepsilon-(\mathrm{FeCo})_{3} \mathrm{~N}$ phases were marked with vertical lines. At the same conditions higher nitriding degree was achieved for the $\mathrm{FeCo}(0.87)$ catalyst, which contains more potassium oxide.

Presence of these phases was confirmed with the roentgen diffraction method, Fig. 8. 
Figure8. XRD patterns of the catalysts after ammonia decomposition at $475^{\circ} \mathrm{C}$.

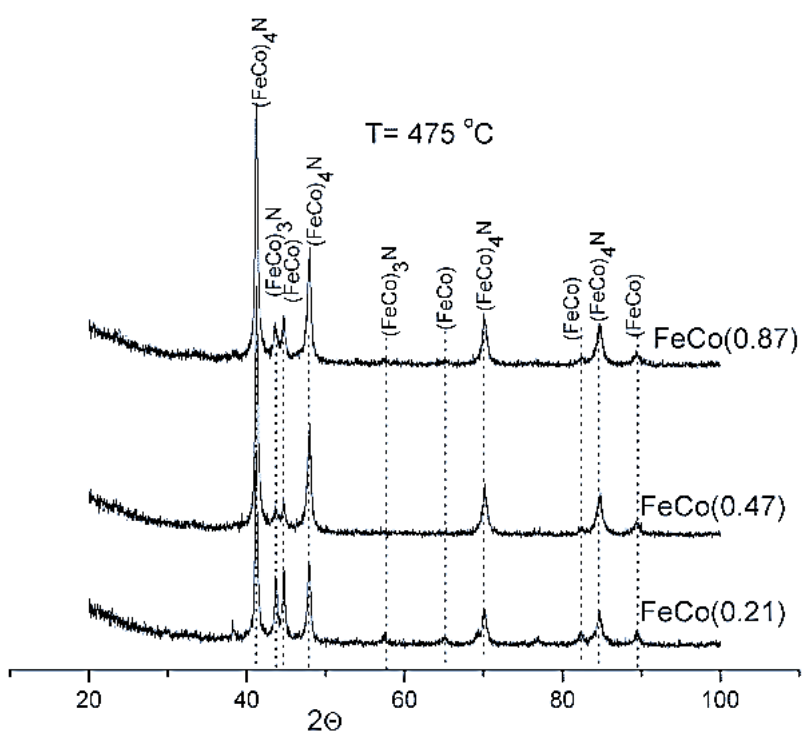

On all X-ray patterns there are visible peaks belonging to $\gamma^{\prime}-(\mathrm{FeCo})_{4} \mathrm{~N}, \quad \varepsilon-(\mathrm{FeCo})_{3} \mathrm{~N}$, and solid solution of iron and cobalt phases.

\section{Conclusions}

Potassium oxide develops specific surface area of the catalyst and increases a number of adsorption sites for hydrogen. An increase in potassium oxide content enhances catalyst activity in the ammonia decomposition reaction. At the temperature of $475{ }^{\circ} \mathrm{C}$ the nitriding process of the catalyst takes place and a new phase is being formed over which the ammonia decomposition rate decreases.

\section{Conflicts of Interest}

State any potential conflicts of interest here or "The authors declare no conflict of interest".

\section{References and Notes}

1. Schlapbach, L.; Züttel, A.; Hydrogen-storage materials for mobile applications. Nature, 2001, 414, 353-358.

2. Chellappa, A.S.; Fischer, C.M.; Thomson, W.J.; Ammonia decomposition kinetics over Ni-Pt/Al ${ }_{2} \mathrm{O}_{3}$ for PEM fuel cell applications. Appl. Catal. A, 2002, 227, 231-240.

3. Yin, S.-F.; Zhang, Q.-H.; Xu, B.-Q.; Zhu, W.-X.; NG, Ch.-F.; Au, Ch.-F.; Investigation on the catalysis of $\mathrm{CO}_{\mathrm{x}}$-free hydrogen generation from ammonia. J. Catal. 2004, 224, 384-396.

4. Yin, S.-F.; et al.; A mini-review on ammonia decomposition catalysts for on site generation of hydrogen for fuel cell applications. Appl. Catal. A,2004, 277, 1-9.

5. Schuth, F.; Palkovits, R.; Schlogl, R.; Su, D. S.; Ammonia as a possible element in an energy infrastructure: catalysts for ammonia decomposition. Energy Environ. Sci., 2012, 5, 6278-6289. 
6. Lendzion-Bielun, Z.; Pelka, R.; Arabczyk, W. Study of the Kinetics of Ammonia Synthesis and Decomposition on Iron and Cobalt Catalysts. Catal. Lett. 2009, 129, 119-121.

7. Choi, J.-G.; Ammonia decomposition over Mo carbide catalysts. J. Ind. Eng. Chem. 2004, 10, 967971.

8. Choi, J.-G.; Ammonia decomposition over vanadium carbide catalysts. J. Catal. 1999, 182, $104-$ 116.

9. Ganley, J.C.; Thomas, F.S.; Seebauer, E.G.; Masel, R.I.; A priori catalytic activity correlations: the difficult case of hydrogen production from ammonia. Catal. Lett. 2004, 96, 3-4.

10. Pelka, R.; Moszynska, I.; Arabczyk, W.; Catalytic ammonia decomposition over Fe/Fe4N. Catal. Lett. 2009, 128, 72-76.

11. Bligaard, T.; et al.; The Bronsted-Evans-Polanyi relations and the volcano curve in heterogeneous catalysis. J. Catal. 2004, 224(1), 206-217.

12. Lendzion-Bieluń, Z.; Arabczyk, W.; Fused FeCo catalysts for hydrogen production by means of the ammonia decomposition reaction, Catal. Today, 2013, 212, 215-219.

13. Hill, A. K.; Torrente-Murciano, L.; In-situ $\mathrm{H}_{2}$ production via low temperature decomposition of ammonia: Insights into the role of cesium as a promoter. Inter. J. Hydro. Ene. 2014, http://dx. doi.org/10.1016.

14. Raróg-Pilecka, W.; Szmigiel, D.; Kowalczyk, Z.; Jodzis, S.; Zielinski, J.; Ammonia decomposition over the carbon-based ruthenium catalyst promoted with barium or cesium. J. Catal. 2003, 218, 465-469.

15. Pelka, R.; Arabczyk, W., A new method for determining the nanocrystallite size distribution in systems where chemical reaction between solid and a gas phase occurs. J. Nanomaterials, 2013, http://dx.doi.org/10.1155/2013/645050

(C) 2014 by the authors; licensee MDPI, Basel, Switzerland. This article is an open access article distributed under the terms and conditions of the Creative Commons Attribution license (http://creativecommons.org/licenses/by/3.0/). 